\title{
A SUMMER OF SWANS
}

CAROL BLENKIN, 801 5th Avenue North, Saskatoon, SK S7K 2N7

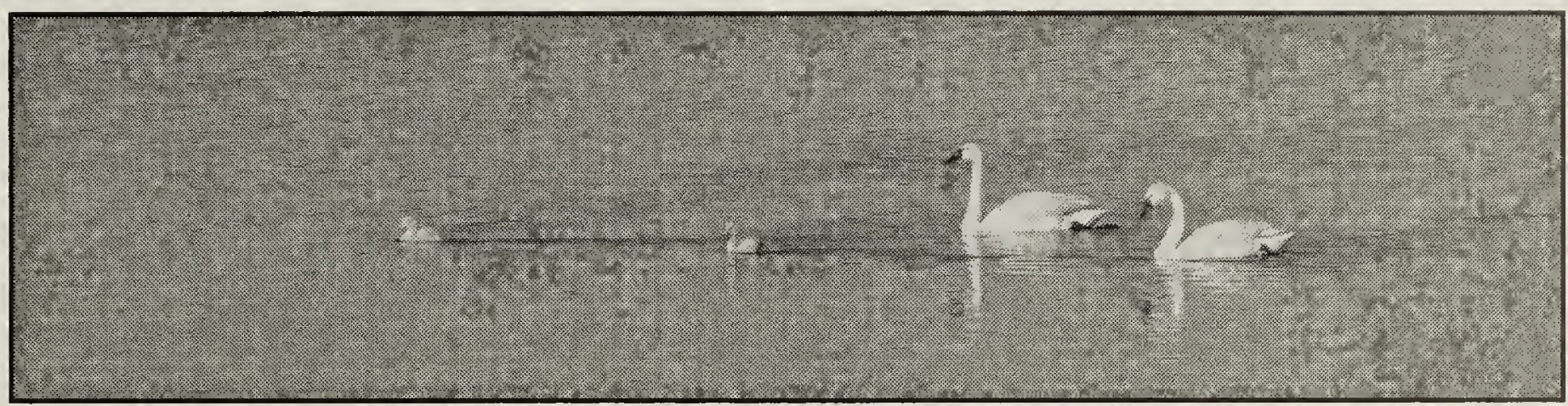

Figure 1. Tundra Swan family east of Saskatoon, June 2003

George Tosh

On Mother's Day, May 11, 2003, a cool, dull day, I discovered a swan nesting on an island in a fresh water pond beside the Patience Lake potash mine $10 \mathrm{~km}$ east of Saskatoon. Doing yeoman work, another swan, presumably the cob, was running on black flipper-like feet after Canada Geese which were landing on the island, before returning to add nesting material to his mate's nest. It was a study in contrast: she, serene; he, frantic.
I enlisted the help of local bird watchers Michael Williams and Stan Shadick to determine whether the swans were Trumpeter or Tundra Swans. Trumpeters have nested in two sites in Saskatchewan: Cypress Hills and Greenwater Lake. Tundras, which usually nest approximately $1500 \mathrm{~km}$ north of this area, have nested at one location in Saskatchewan: Stony Lake, $90 \mathrm{~km}$ north of North Battleford from 19731980.,3 Careful observation revealed yellow

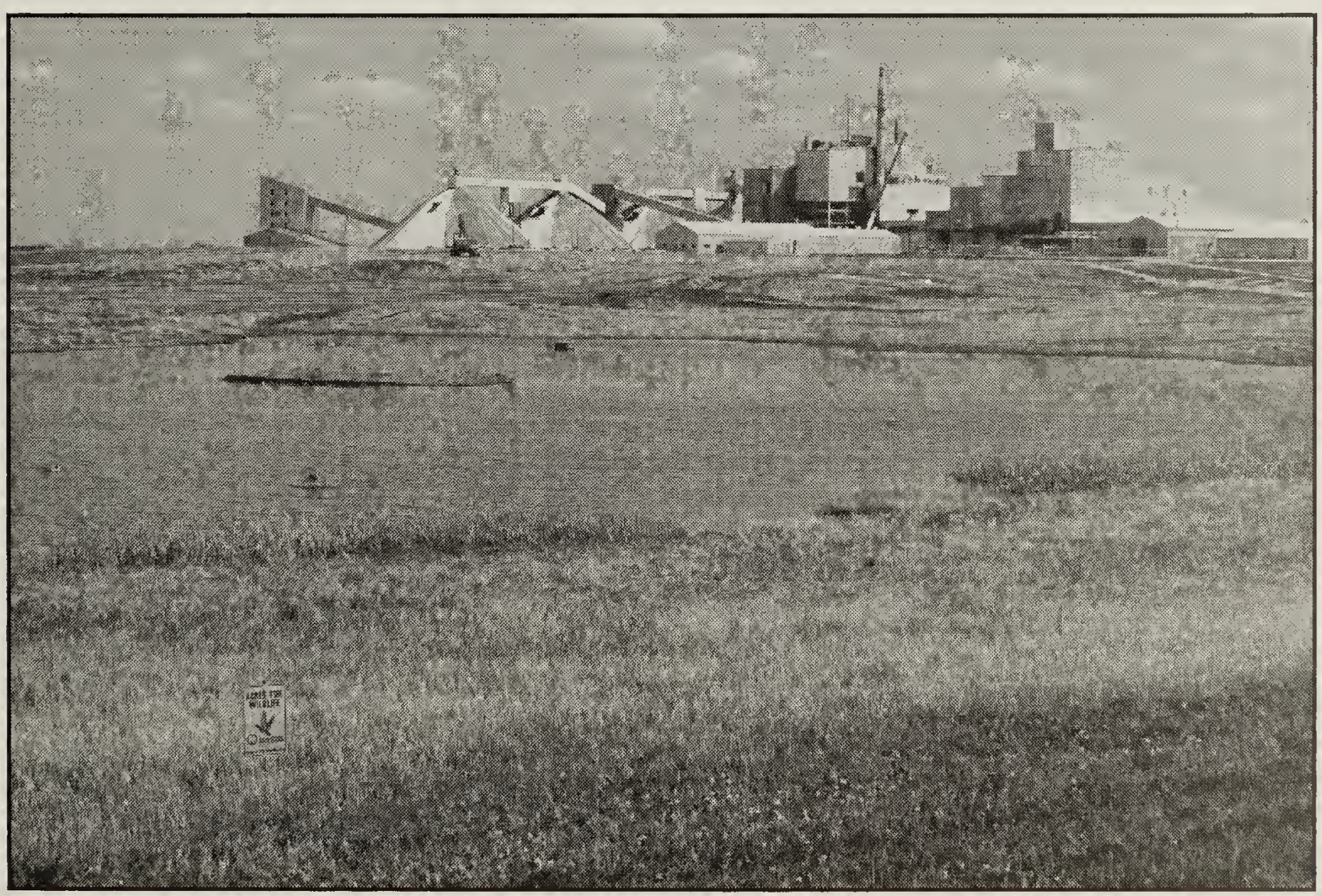

Figure 2. Location of the swan nesting island in relation to the potash mine

George Tosh 


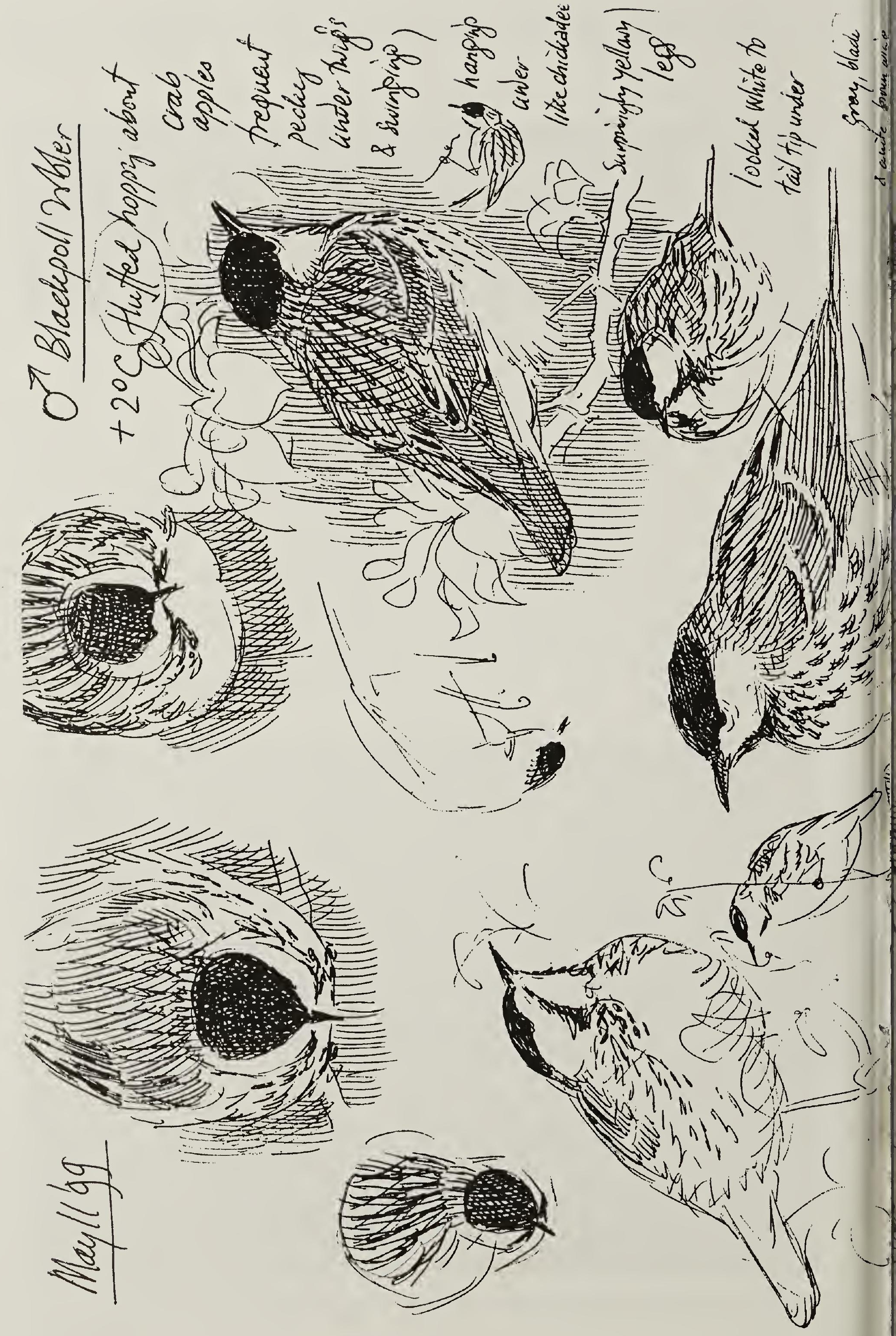


lores which confirmed that they were Tundra Swans, and many of us were able to observe, for a first time, a summer season of these magnificent birds nesting in a natural, albeit human-altered, environment (Figure 2).

The nest pond is on mine property immediately west of the tailings pile and is bordered by Provincial Highway 316 . The water level in the 4 ha pond is maintained with fresh water from the South Saskatchewan River piped in, in stages, through a string of ponds as part of a soil reclamation project. The swans were well situated for the literally hundreds of visits they received. Parking along the rather steep shoulder of the road and using the vehicle as a blind was the ideal way to observe them. Large trucks regularly passed by, and the swans and over twenty other species of birds, seemed to ignore the vehicles on one side and mine equipment on the other.

At 11 am on June 13th, 34 days after the swans were first seen on the nest and just before Father's Day, Hilda and Bruce Noton and I were delighted to see two cygnets swimming with one of the adult swans. The other adult remained on the nest. Earlier that morning, Sue Taylor, who ran by the pond almost daily, had observed only one cygnet indicating that the second must have hatched just a few hours after the first. Tundra Swans lay 4-5 eggs and they hatch in 35-40 days. ${ }^{2}$ One adult continued to sit on the nest for 23 more days but no more young hatched. It was impossible to see what the nest bowl contained when the swan moved off briefly.

When first noted, the young were approximately half the size of the Canvasbacks and Gadwalls that floated beside them and shared the vegetation stirred up by the up-ended, paddling adult swans. The cygnets were gray overall, on both down and bills. Their feet were pinkish, dramatically different from the adults' large, very black feet visible during food forays on the bottom (see back cover of the June 2003 Blue Jay). The adult swan swimming with the cygnets cooed softly and called to them. At $7 \mathrm{pm}$ on their first day on earth, the siblings engaged in a slight tussle: on the island they faced off and began darting their heads at each other and neck wrestling. It was the only time I saw them do this.

At $6 \mathrm{pm}$ that day the adult still on the nest waddled to the water's edge and began pulling up greens and moving sticks. After a

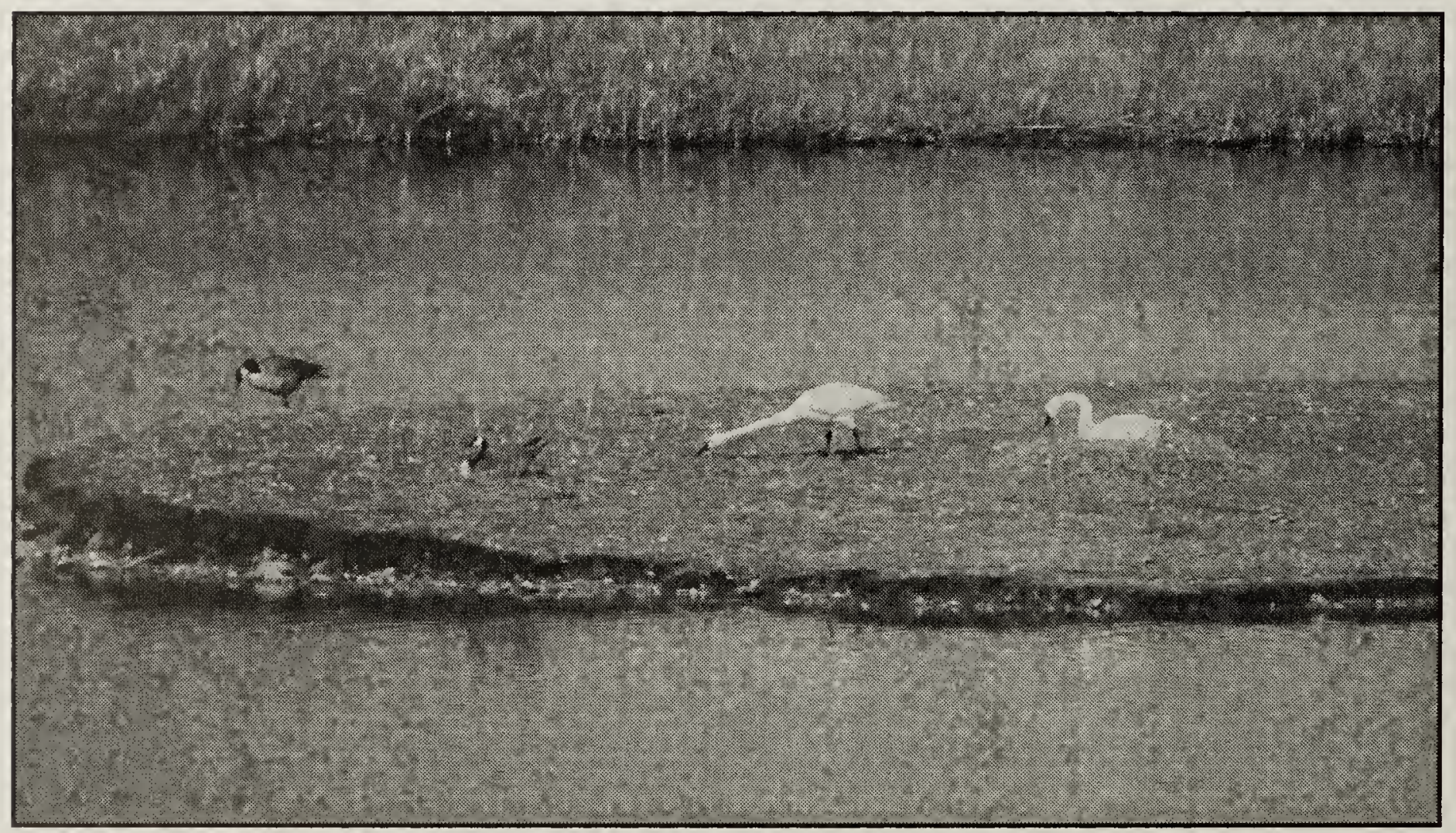

Figure 3. Tundra Swans co-habiting the nest island with Canada Geese

George Tosh 
short swim behind the island it climbed ashore followed by an irate avocet which repeatedly attacked the retreating swan from behind. The swan did not react but blithely climbed back into the nest.

When the cygnets were a week old, and tipping and stirring up food, the Canada Goose which had been allowed to nest near the swans on the island (Figure 3) was forced to abandon her nest. About eight exposed goose eggs disappeared over the next few days. Two or three avocets (Figure 4) were also nesting on the small island but no one reported seeing any avocet young. The swans not only blocked geese from the island, they tried to chase them off the pond. In one instance, the swan, gliding around the edge of the pond, ran out of the water with wings spread wide, at a point just below seven sleeping geese. It startled them and chased two of them as they marched along the potash mine railway track leading away from the mine. The pursued and pursuer walked along the track at a steady pace, the geese crooking their necks back, keeping an eye on the advancing swan until it turned and went back to the water. On a subsequent visit, however, I observed a Canada Goose walk slowly over to the abandoned swan's nest on the island, tentatively step up into it and look around expectantly.

For the first month the cygnets remained close to one of the adults on the pond or on the island while the other adult swam elsewhere in the same pond, in the channel to the east, or in the larger pond to the north. The adults were rarely observed in flight. At a month old, the cygnets were about half the size of their parents and remained quite gray with a black border on their bills.

While eating some red Samphire (Salicornia rubra), one of the cygnets spread its wings which were so undeveloped that they looked like plucked and floured chicken wings! This was on July 14 and was the first time I observed the cygnets not under the supervision of one or both parents. They were at their usual place, near the nest site, with their heads periscoping up through the weeds and moving from side to side. One was opening and closing its bill, as if calling the parents. Within minutes both adult swans appeared. It was the last day I saw all four swans.

On August 8th, George Tosh, who had been observing and photographing the family

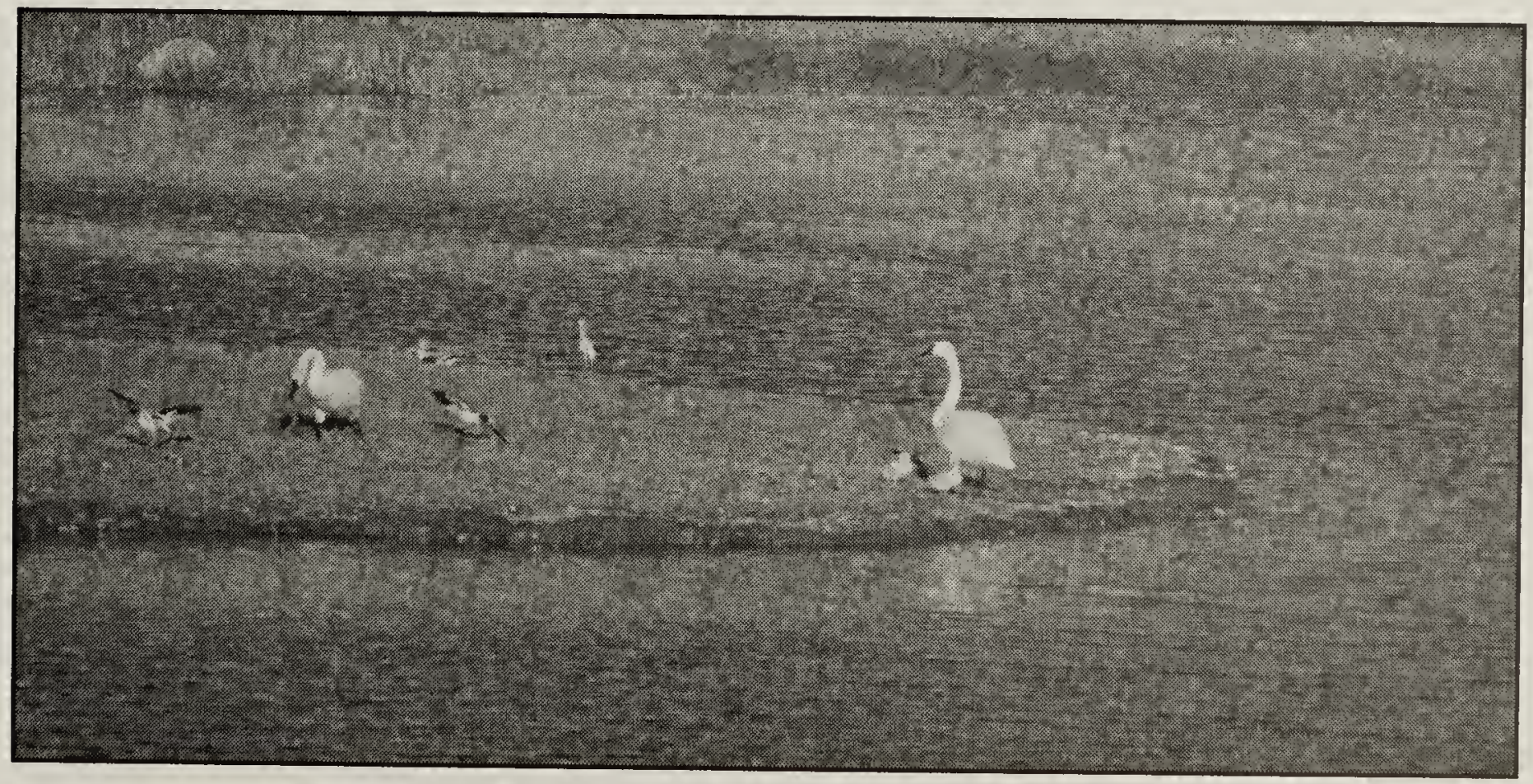

Figure 4. Tundra Swans and American Avocets on the swan nest island 
regularly, reported one of the cygnets missing. We suspect that a coyote was involved as one was seen near the pond by Frank Roy, and Darlene and Jim Hay, on a previous visit. Following the loss of one cygnet, both parents usually kept a close watch on the remaining one. The cygnet was turning white on its breast while retaining a gray colour overall.

On September 21, when the cygnet was 100 days old, I observed the three swans in a slough approximately $200 \mathrm{~m}$ north of the pond containing the nest. I had never seen the cygnet away from the nest pond before. The family swam to a rock and, after preening (Figure 5), all three flew in a wide circle and landed on the water near the opposite shore. While the adults trudged up the bank, the cygnet flew in a graceful arc over them and landed slightly ahead of the adults, seeming to revel in his new found skill. These were the first and only observed flights of the cygnet and the last time the family was seen at the potash mine.
On October 16, two adult swans and a cygnet, that looked like the potash mine swans, flew in and joined two adults on a slough south of Bradwell. Five days later 18 migrating swans were on the same slough when this family group flew in with loud woo-hooing from both parties (Figure 6). Could they have been discussing the relative rights of migrants and residents to the rich vegetation of a prairie pond? One of the newly-arrived adults swam over to one of those on the slough and they had a no-contact neck wrestle.

Were the nesting pair of Tundra Swans arctic birds that opted to remain on the prairies or were one or both birds part of the group of resident Tundra Swans at the Forestry Farm Park and Saskatoon Zoo in Saskatoon? The park's resident pair had produced two cygnets circa 1997 which migrated in the fall (Greg Fenty, pers. comm.). In 1998, a pair of feral adults spent the summer on the marsh in the park but produced no young. In 1999, 2000 and 2001

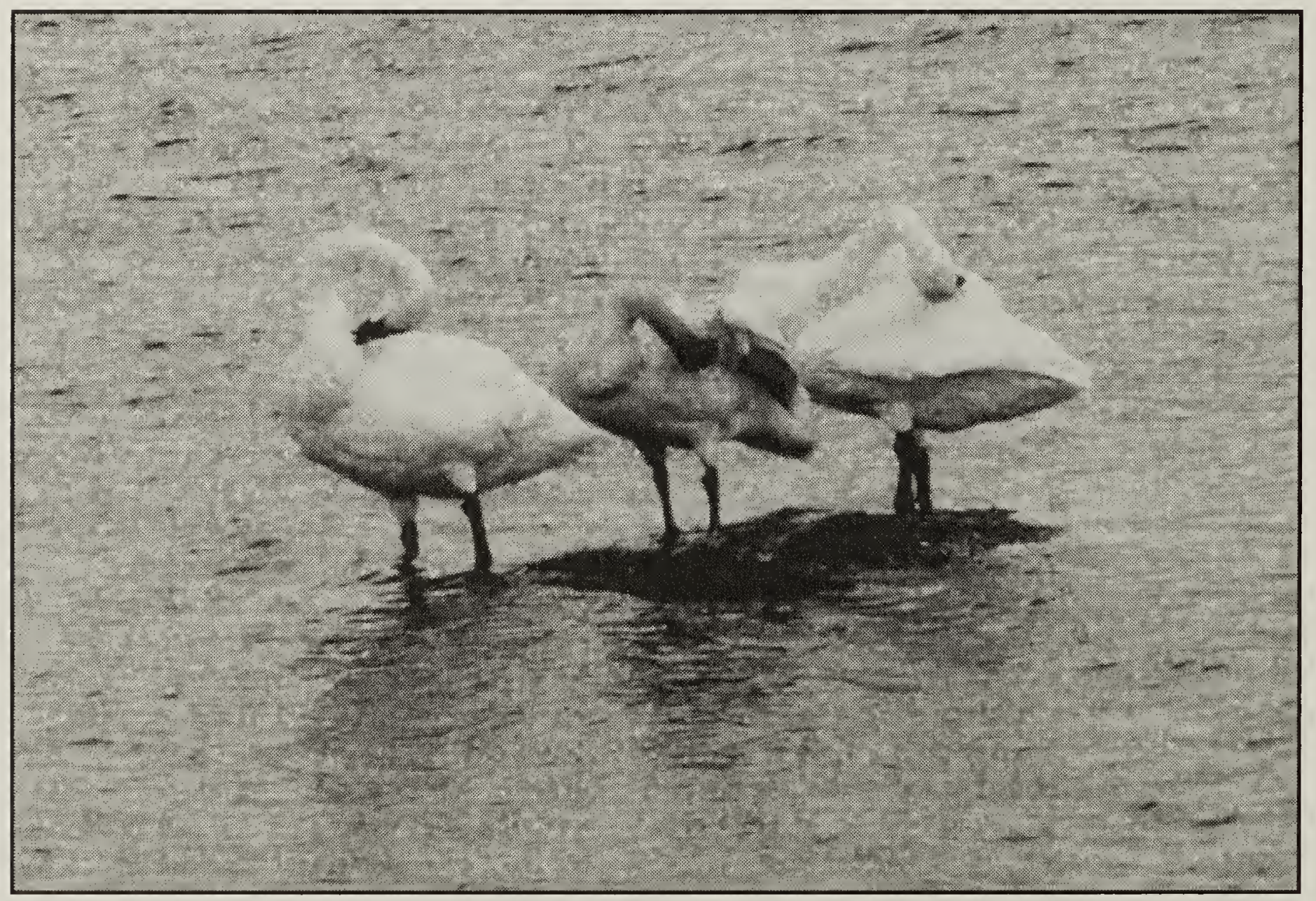

Figure 5. Swans preening a few seconds before take-off, 21 September 2003

Carol Blenkin 


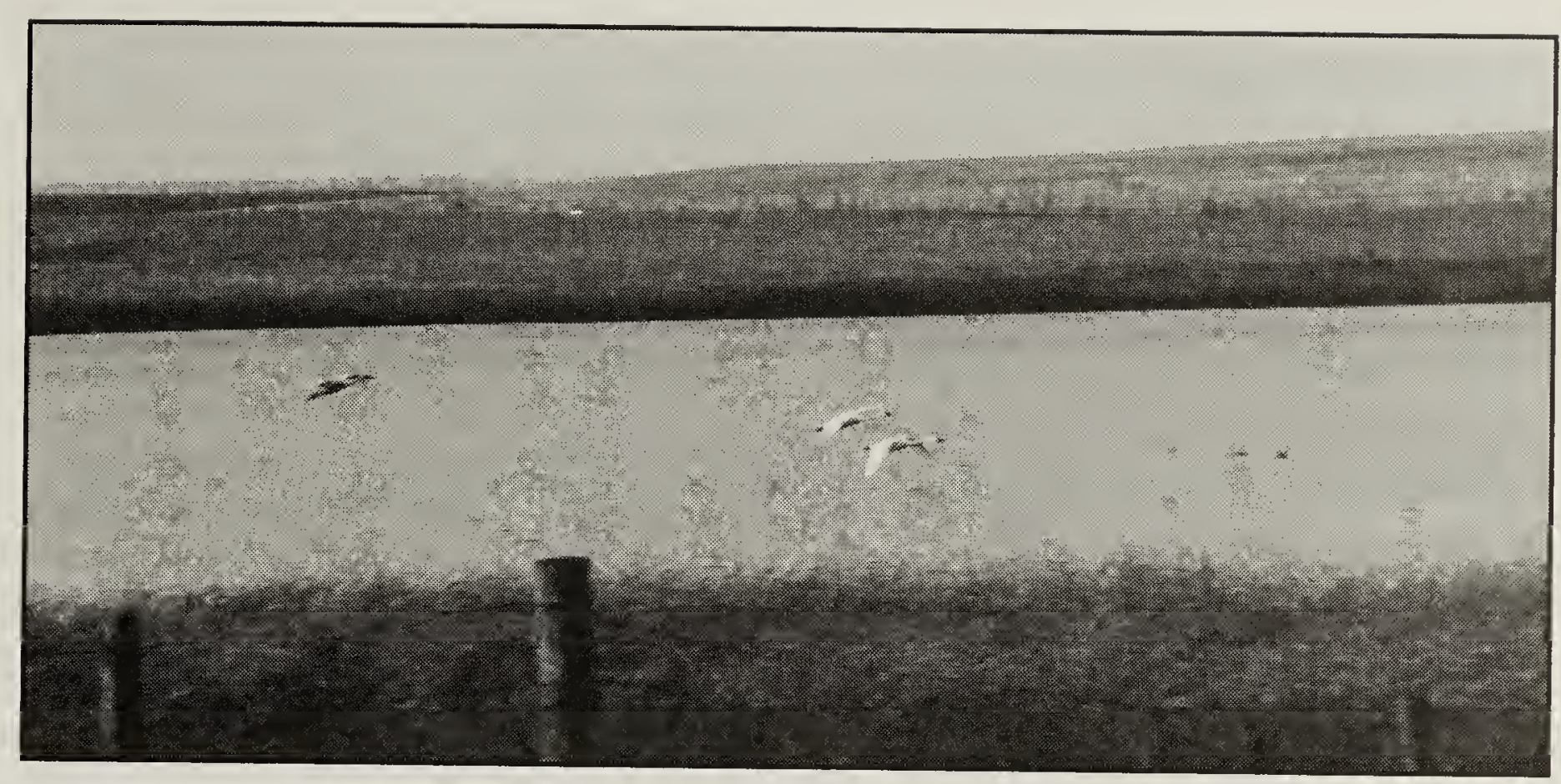

Figure 6. Three swans in flight, Bradwell, 22 October 2003

Carol Blenkin

two swans again spent the summer in the park and, each year, they produced offspring which did not survive. In 2002, only one swan was at the park but two Tundra Swans were seen that summer at the Northeast swale, three km NE of the Foresrty Farm Park (Frank Roy, pers. comm). Also in 2002, Sue Taylor, Hilda and Bruce Noton, and James Couch, General Superintendent of the Patience Lake Division of the Potash Corporation of Saskatchewan, observed two adults throughout the summer on the pond beside the Patience Lake potash mine. In 2003, two swans returned to the Zoo and produced eggs but no young. None of the observed swans was banded.

The Tundra Swans made a strong impression on observers in 2003. James Couch said that he and the 67 employees on the mine site were very excited when the swans returned in 2003 and nested successfully. They brought their children and grandchildren out to see them. The swans were a regular topic of conversation with the dog retriever club members who saw them as they made a daily drive to their training grounds. CFQC TV produced a story that aired on the provincial newscast and the Star Phoenix ran their picture.

Will they return? The average spring arrival date for migrating Tundra Swans to reach the Saskatoon area is April 11. There will be scores of swan converts watching and hoping that a breeding pair will call the prairies home again this summer.

1. SMITH, A. R. 1996. Atlas of Saskatchewan Birds. Saskatchewan Natural History Society Publication No. 22. Regina, SK.

2 BENT, ARTHUR CLEVELAND. 1962. Life Histories of North American Wild Fowl, Part Two pp 281-293. Dover Publications, New York.

3 NIEMAN, D.J., J.K GODWIN, and J.R. SMITH, 1983 Whistling Swans breeding in Saskatchewan parkland. Blue Jay, 41(2):65-128

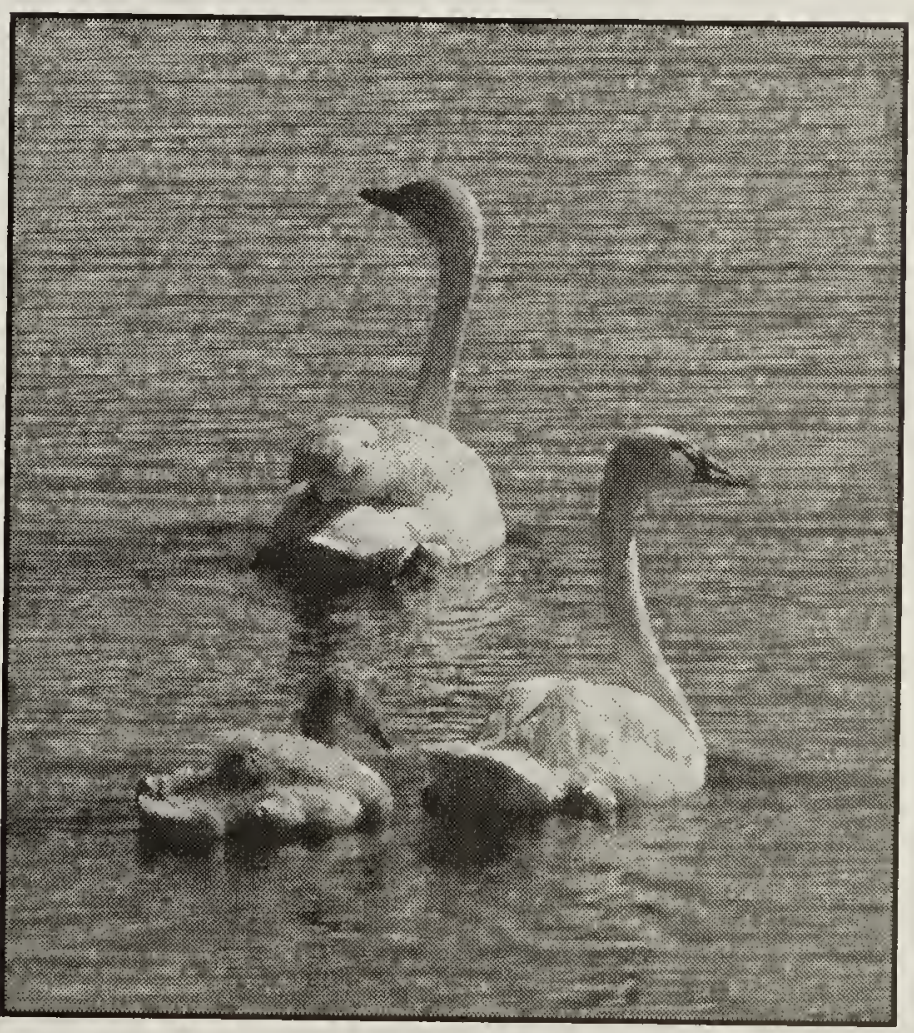

Tundra Swan family east of Saskatoon

George Tosh 